\title{
Myxozoan infections in fishes of the Tasik Kenyir Water Reservoir, Terengganu, Malaysia
}

\author{
Cs. Székely ${ }^{1, *}$, F. Shaharom-Harrison ${ }^{2}$, G. Cech $^{1}$, G. Ostoros ${ }^{1}$, K. Molnár ${ }^{1}$ \\ ${ }^{1}$ Veterinary Medical Research Institute, Hungarian Academy of Sciences, PO Box 18, 1581 Budapest, Hungary \\ ${ }^{2}$ Institute of Tropical Aquaculture, University Malaysia Terengganu, 2130 Kuala Terengganu, Terengganu, Malaysia
}

\begin{abstract}
During a survey on fishes of the Tasik Kenyir Reservoir, Malaysia, 5 new Myxobolus spp. and 2 known Henneguya spp. were found. The specific locations for 2 Myxobolus spp. were the host's muscles, while 2 other Myxobolus spp. were found to develop in the host's kidney and gills, respectively. Of the species developing intracellularly in muscle cells, $M$. terengganuensis sp. nov. was described from Osteochilus hasselti and M. tasikkenyirensis sp. nov. from Osteochilus vittatus. M. csabai sp. nov. and M. osteochili sp. nov. were isolated from the kidney of Osteochilus hasselti, while M. dykovae sp. nov. was found in the gill lamellae of Barbonymus schwanenfeldii. Henneguya shaharini and Henneguya hemibagri plasmodia were found on the gills of Oxyeleotris marmoratus and Hemibagrus nemurus, respectively. Description of the new and known species was based on morphological characterization of spores, histological findings on locations of plasmodia and DNA sequence data.
\end{abstract}

KEY WORDS: New species $\cdot$ Myxosporea $\cdot$ Myxobolus $\cdot$ Henneguya $\cdot$ Histology $\cdot 18 \mathrm{~S}$ rDNA

\section{INTRODUCTION}

Research on myxosporean fish parasites is a fastdeveloping field of ichthyoparasitology. Numerous myxosporeans, among them highly pathogenic species, are known from freshwater and marine fishes. In terms of freshwater fishes, the majority of studies both in freshwater and culture systems deal with fishes of the northern hemisphere (Eurasia and North America), while studies on myxosporeans of marine fishes have mostly been done worldwide on cage-cultured species. Among myxosporeans, the genus Myxobolus includes the highest number of species. In a synopsis of this genus, Eiras et al. (2005) reported 751 valid species, while Lom \& Dyková (2006) counted 792 known species. Henneguya spp. also belong to the commonest parasites of fishes, and in his review of this group Eiras (2002) listed 146 Henneguya spp. mostly from fishes of the temperate climate zones. The genus Thelohanellus is a less well studied myxosporean group but several of the known species have been precisely described from South Asia. Most of the papers written on myxosporean parasites of the tropical and subtropical coun- tries have been presented by Indian authors (Chakravarty 1939, Tripathi 1952, Lalitha-Kumari 1965, 1969, Seenappa \& Manohar 1981, Sarkar 1985, 1986, 1995, Sarkar et al. 1985, Basu \& Haldar 2003, 2004). Data on myxosporean infections were also presented by Ky (1971) from Vietnam and a review of the known fish parasites of this country was written by Arthur \& Te (2006). Studies on several species were also done in Thailand. From that country, first Lom et al. (1991) described a new genus, Hennegoides, with Hennegoides longitudinalis as type species, then Supamattaya et al. (1991) reported on Sphaerospora epinepheli from the grouper Epinephelus malabaricus cultured in marine cages. A third species is $S$. ojiroveci from an aquarium fish originating from Thailand, but described by Lom \& Dyková (1997) in Europe. More recently, $M$. balantiocheili, a species causing neurological symptoms, was described from the brain of Balantiocheilos melanopterus in Thailand (Levsen et al. 2004). The first paper on a myxosporean infection of Malaysian fishes was written by Shariff (1982), who presented a complex morphological and pathological study on the new species Henneguya shaharini. 
Recently, additional myxosporeans have been found by Molnár et al. (2006a,b) from Pangasius hypophthalmus and Hemibagrus nemurus. They described 3 Hennegoides, 2 Myxobolus and 4 Henneguya species from these fishes.

Lake Tasik Kenyir was formed by the construction of 2 major dams in 1982. The total water surface area of the lake is about 36900 ha, with a surrounding catchment area of 260000 ha. The shoreline of this lake is rather steep since it was formed in a hilly terrain. The average depth of the lake is about $100 \mathrm{~m}$. Surface temperatures of the lake do not fluctuate very much (around 28 to $30^{\circ} \mathrm{C}$ ), while in the upstream portions of the feeding rivers, water temperatures as low as $23.0^{\circ} \mathrm{C}$ have been recorded. The fish fauna that once dominated the upstream and downstream rivers has presumably adapted to the lacustrine habitat. At least 38 fish species are known to occur in the lake, 17 of which are economically important for their market price or aquarium trade value (Zulkafli \& Ashhar 2000).

The aim of the present study was to get information on myxosporean infections of fishes in the southeast Asian region. Five new Myxobolus spp. are described and the occurrence of 2 known Henneguya spp. is recorded from fishes of Tasik Kenyir, and the site selection in the infected organs and phylogenetic positions of these parasites are discussed.

\section{MATERIALS AND METHODS}

Study location and sample preparation. Fishes were collected with the help of gill nets in the Tasik Kenyir Water Reservoir on 20 and 21 April 2007 (area 'Anglers Paradise', 5² $\left.12.057^{\prime} \mathrm{N}, 102^{\circ} 40.159^{\prime} \mathrm{E}\right)$. The following fishes of various size and age classes (a total of 15 species) were examined for myxozoan infections on the spot or 1 to $3 \mathrm{~d}$ later in the laboratory of the Institute of Tropical Aquaculture (AQUATROP), University Malaysia Terengganu (UMT): Neolissochilus (Acrosocheilus) hexagonolepis (copper mahseer, tengas) ( $\mathrm{n}=2$ ), Cyclocheilichthys apogon (Indian river barb, temperas) ( $\mathrm{n}=6)$, Epalzeohynchos kalopterus (selimang) ( $\mathrm{n}=2$ ), Hampala macrolepidota (hampala barb, sebarau) $(\mathrm{n}=5)$, Labiobarbus lineatus (kawan) ( $\mathrm{n}=4$ ), Mystacoleucus marginatus (sia) ( $\mathrm{n}=5)$, Osteochilus vittatus (bonylip barb, rong) ( $\mathrm{n}=4$ ), Osteochilus hasselti (silver shark minnow, terbol) ( $\mathrm{n}=10$ ), Barbonymus schwanenfeldii (tinfoil barb, lampam sungai) ( $\mathrm{n}=10)$, Oxyeleotris marmoratus (marble goby, ketutu) $(\mathrm{n}=2)$, Pristolepis fasciatus (patung) ( $\mathrm{n}=1)$, Notopterus notopterus (bronze featherback, belida) $(\mathrm{n}=3)$, Hemibagrus nemurus (Asian redtail catfish, baung) ( $\mathrm{n}=2)$, Channa micropeltes (snakehead, toman) ( $\mathrm{n}=2$ ) and Osphronemus gouramy (giant gouramy, kalui) ( $\mathrm{n}=1)$.

After surveying the skin, the fins and the gills in toto, the gills were cut out, the abdominal cavity opened, the intestine, spleen, liver, gonads and kidneys separated and checked mostly with the unaided eye and in some cases by Zeiss Stemi DV4 stereomicroscope and Motic DMBA300 digital microscope. Detailed (microscopic) investigations were performed only on the gills and the muscles. The hemibranchial area was studied in detail. From the muscles only, several cubes of about $1 \mathrm{~g}$ were cut out from 3 different parts of the body.

The gill filaments of each hemibranchium were checked for myxozoan plasmodia under a Zeiss Stemi DV4 stereomicroscope. Plasmodia in filaments, lamellae or in the gill arches were differentiated according to Molnár (2002) into epithelial, vascular, muscular and chondroid locations. Plasmodia were carefully removed from the tissues and opened with a fine needle in a slide. Some of the spores obtained from mature plasmodia were studied as fresh preparations under a Motic DMBA300 digital microscope, and other spores obtained from the same plasmodia were fixed in $70 \%$ ethanol in vials for further morphological and molecular biological examination. Pieces from the muscles were compressed between 2 glass slides and studied as squash preparations under a compound microscope. Photos of fresh spores were taken with a Motic DMBA300 digital microscope. Infected organs (hemibranchia of gills, kidney and muscles) were fixed in Bouin's solution for $4 \mathrm{~h}$, washed in $80 \%$ ethanol several times, embedded in paraffin wax, cut into 5 to $8 \mu \mathrm{m}$ thick sections and stained with hematoxylin and eosin. Photos of histological sections were taken in Hungary with an Olympus BH-2 microscope equipped with a DP-10 digital camera. Measurements were taken of 25 photographed fresh spores according to the guideline suggested by Lom \& Arthur (1989).

Molecular methods. For DNA extractions, samples preserved in ethanol were centrifuged at $5000 \times g$ for 5 min to pellet the myxospores, then the ethanol was removed. The DNA was extracted using a QIAGEN DNeasy tissue kit (animal tissue protocol; Qiagen) and eluted in $50 \mu \mathrm{l}$ AE buffer.

The 18S rDNA was amplified using the primers $18 \mathrm{e}$ and $18 \mathrm{~g}^{\prime}$ (Table 1 ) in a $25 \mu$ reaction mixture comprising $1 \mu \mathrm{l}$ of extracted genomic DNA, $5 \mu \mathrm{l}$ of $1 \mathrm{mM}$ deoxyribonucleotide triphosphates (dNTPs, MBI Fermentas), $0.25 \mu \mathrm{l}$ of each primer $\left(50 \mathrm{pmol} \mu \mathrm{l}^{-1}\right), 2.5 \mu \mathrm{l}$ of $10 \times$ Taq buffer (MBI Fermentas), $2 \mu \mathrm{l}$ of $25 \mathrm{mM} \mathrm{MgCl}_{2}$, $1 \mu \mathrm{l}$ of Taq polymerase (2 U) (MBI Fermentas) and $13 \mu \mathrm{l}$ of distilled water. The PCR cycle consisted of an initial denaturation step of $94^{\circ} \mathrm{C}$ for $4 \mathrm{~min}$, followed by 35 cycles of $94^{\circ} \mathrm{C}$ for $50 \mathrm{~s}, 56^{\circ} \mathrm{C}$ for $50 \mathrm{~s}, 72^{\circ} \mathrm{C}$ for $80 \mathrm{~s}$, and 
Table 1. Primers used for PCR or sequencing

\begin{tabular}{|lll|}
\hline Primer & Sequence & Source \\
\hline 18e & 5'-CTG GTT GAT TCT GCC AGT-3' & Hillis \& Dixon (1991) \\
18g' & 5'-CGG TAC TAG CGA CGG GCG GTG TG-3' & Hillis \& Dixon (1991) \\
SphF & 5'-ACT CGT TGG TAA GGT AGT GGC T-3' & Eszterbauer \& Székely (2004) \\
SphR & 5'-GTT ACC ATT GTA GCG CGC GT-3' & Eszterbauer \& Székely (2004) \\
MC5 & 5'-CCT GAG AAA CGG CTA CCA CAT CCA-3' & Molnár et al. (2002) \\
MC3 & 5'-GAT TAG CCT GAC AGA TCA CTC CAC A-3' & Molnár et al. (2002) \\
MB5r & 5'-ACC GCT CCT GTT AAT CAT CAC C-3' & Eszterbauer (2004) \\
MB5f & 5'-GAT GAT TAA CAG GAG CGG TTG G-3' & Eszterbauer (2004) \\
\hline
\end{tabular}

was finished with terminal extension at $72^{\circ} \mathrm{C}$ for $7 \mathrm{~min}$, then rested at $4^{\circ} \mathrm{C}$.

This was followed by a second round of PCR with the SphF-SphR primer pair (Table 1). The total volume of the nested PCR reactions was $50 \mu \mathrm{l}$, which contained $1 \mu \mathrm{l}$ of amplified DNA, $10 \mu \mathrm{l}$ of $1 \mathrm{mM}$ dNTPs, $0.5 \mu \mathrm{l}$ of each primer, $5 \mu$ l of $10 \times$ Taq buffer, $2.5 \mu$ of $25 \mathrm{mM}$ $\mathrm{MgCl}_{2}, 2 \mu \mathrm{l}$ of $\mathrm{Taq}$ polymerase $(2 \mathrm{U})$ and $28.5 \mu \mathrm{l}$ of DEPC water. Amplification conditions in the second round were $94^{\circ} \mathrm{C}$ for $50 \mathrm{~s}, 56^{\circ} \mathrm{C}$ for $50 \mathrm{~s}, 72^{\circ} \mathrm{C}$ for $60 \mathrm{~s}$ for 35 cycles, and the cycle was terminated with an extension period at $72^{\circ} \mathrm{C}$ for $10 \mathrm{~min}$, then rested at $4^{\circ} \mathrm{C}$. Both PCR cycles were performed in a PTC-200 thermocycler (MJ Research). The PCR products were electrophoresed in $1.0 \%$ agarose gels in tris-acetate-EDTA (TAE) buffer gel stained with $1 \%$ ethidium bromide and then purified with the PCR-M Clean Up System (Viogene).

Purified PCR products were sequenced in both directions with the primers listed in Table 1, using the ABI BigDye Terminator v3.1 Cycle Sequencing Kit with an ABI 3100 Genetic Analyser.

The various forward and reverse sequence segments were aligned in BioEdit (Hall 1999) and ambiguous bases clarified using corresponding ABI chromatograms. Nucleotide sequences were aligned using the software CLUSTAL W (Thompson et al. 1994). The alignment was corrected manually using the alignment editor of the software MEGA 4.0 (Tamura et al. 2007). DNA sequence similarities were calculated with the Sequence Identity Matrix of the software BioEdit. Phylogenetic calculations were performed with PAUP 4.0b10 (Swofford 2000). The data were analyzed with maximum parsimony (closeneighbor-interchange [CNI] level 3, random addition trees 100). Also neighbor-joining was calculated by MEGA 4.0 using the Tamura-Nei model and pairwise deletion for gaps. Clade support was assessed with bootstrapping (100 replicates for maximum likelihood and maximum parsimony and 1000 replicates for neighbor-joining). Ceratomyxa shasta was chosen as an outgroup.

\section{RESULTS}

Myxozoan infection was found in 5 out of the 15 fish species examined. Plasmodia with mature Myxobolus spp. spores were found in the musculature of Osteochilus vittatus and $O$. hasselti. In O. hasselti, Мухоbolus spores of 2 species were found in the kidney, while in Barbonymus schwanenfeldii, plasmodia of Myxobolus spp. were found in the gills. Besides Myxobolus spp., the occurrence of 2 known Henneguya spp. was demonstrated in the gills: $H$. shaharini in marble goby and $H$. hemibagri in Asian redtail catfish.

\section{Myxobolus terengganuensis sp. nov.}

Type host: Silver shark minnow Osteochilus hasselti (Valenciennes, 1842) (Cyprinidae). Local name: ikan terbol.

Type locality: Lake Tasik Kenyir, Malaysia.

Site of tissue development: Muscle. Mature disporoblastic plasmodia located intracellularly in muscle cells were elongated, up to 500 to $700 \mu \mathrm{m}$ in length. Only old plasmodia filled with spores were found.

Type material: Digitized photos of syntype spores and histological sections were deposited in the parasitological collection of the Zoological Department, Hungarian Natural History Museum, Budapest, coll. no. HNHM-70080. The 18S rDNA sequence of Myxobolus terengganuensis sp. nov. was deposited in GenBank under accession no. EU643629.

Prevalence of infection: $1 / 10$ of 10 to $22 \mathrm{~cm}$ sized fish.

Etymology: The species was named after Terengganu State, Malaysia.

Spores: The spores (Figs. 1a \& 2a) were ellipsoidal in frontal view. In sutural view they had an elongatedellipsoidal shape (Fig. 1b). Length of the spores was $12.7 \pm 0.51$ (range, 12 to 13.4$) \mu \mathrm{m}(\mathrm{n}=50)$, width $7.4 \pm$ 0.53 (range, 6.7 to 8.3$) \mu \mathrm{m}(\mathrm{n}=50)$, thickness $5 \pm 0.21$ (range, 4.8 to 5.2$) \mu \mathrm{m}(\mathrm{n}=15)$. Polar capsules were elongated, different in size, slightly converging anteri- 
orly. Larger capsule was $6.8 \pm 0.40$ (range, 6.2 to 7.3) $\mu \mathrm{m}$ long $(\mathrm{n}=50$ ) and $3.2 \pm 0.14$ (range, 2.9 to 3.4) $\mu \mathrm{m}$ wide $(\mathrm{n}=50)$. Smaller capsule was $5 \pm 0.42$ (range, 4.4 to 5.5$) \mu \mathrm{m}$ long $(\mathrm{n}=50)$ and $2.3 \pm 0.13$ (range, 2.2 to 2.6 ) $\mu \mathrm{m}$ wide. Filament coils could not be observed in the capsules. No intercapsular appendix was seen. The width of the suture was $5.4 \pm 0.40$ (range, 5 to 6 ) $\mu \mathrm{m}$. Sutural edge markings were not seen. A single binucleated sporoplasm with round iodinophilous vacuole was asynchronous in shape. Mucous envelope was not found.

Molecular data: The 18S rDNA of Myxobolus terengganuensis sp. nov. was related to that of another muscle-infecting species described from European habitats (see Figs. $10 \& 11$ ). Based on the nucleotide sequences, M. pseudodispar (GenBank accession no. AF380145) appears to be its closest relative with $95.4 \%$ similarity. A $94.9 \%$ homology with $M$. musculi and a 94.1\% homology with $M$. cyprini were observed.

Histology: Spores were found in elongated intracellular plasmodia inside the muscle cells. In more progressed cases of plasmodial development, the infected muscle cells became disrupted and masses of spores were located among the neighboring muscle cells surrounded by histiocytes and melanin-containing macrophages (Fig. 3). Very often spores were associated with metacercariae of a closely non-identified trematode species infecting the musculature of this fish (Fig. 4a). Myxobolus spores were often found inside metacercarian cysts (Fig. 4b). In some cases the cysts formed by closely non-identified metacercariae could no longer be recognized, but among the muscle cells nodules containing mature spores infiltrated and surrounded by melano-macrophage cells were observed (Fig. 4c).

Remarks: By its elongated spores of varying size and by its intracellular location, this species most closely resembles the muscle-dwelling species of the Myxobolus cyprini group (M. musculi, M. pseudodispar) which is supported by the relatively high similarity of the $18 \mathrm{~S}$ rDNA sequences. However, the members of the $M$. cyprini group infect genetically different hosts.

\section{Myxobolus tasikkenyirensis sp. nov.}

Type host: Bonylip barb Osteochilus vittatus (Valenciennes, 1842) (Cyprinidae). Local name: ikan rong.

Type locality: Lake Tasik Kenyir, Malaysia.

Site of tissue development: Plasmodia and spores of this species were found in the muscles.

Type material: Digitized photos of syntype spores and histological sections were deposited in the parasitological collection of the Zoological Department, Hungarian Natural History Museum, Budapest, coll. no. HNHM-70081. The 18S rDNA sequence of Myхobolus tasikkenyirensis sp. nov. was deposited in GenBank under accession no. EU643626.
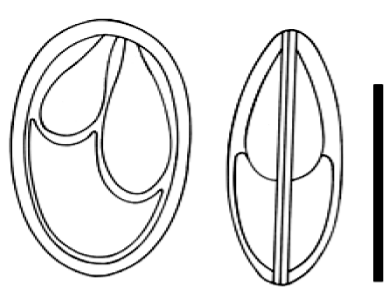

b

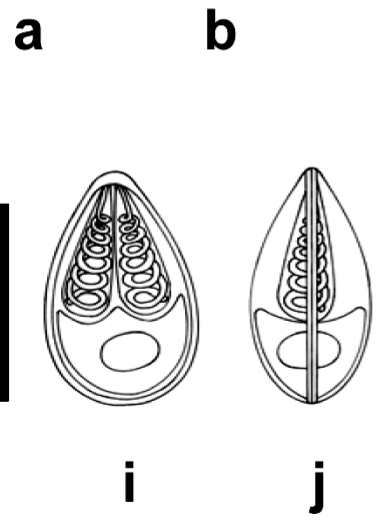

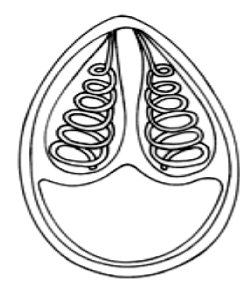
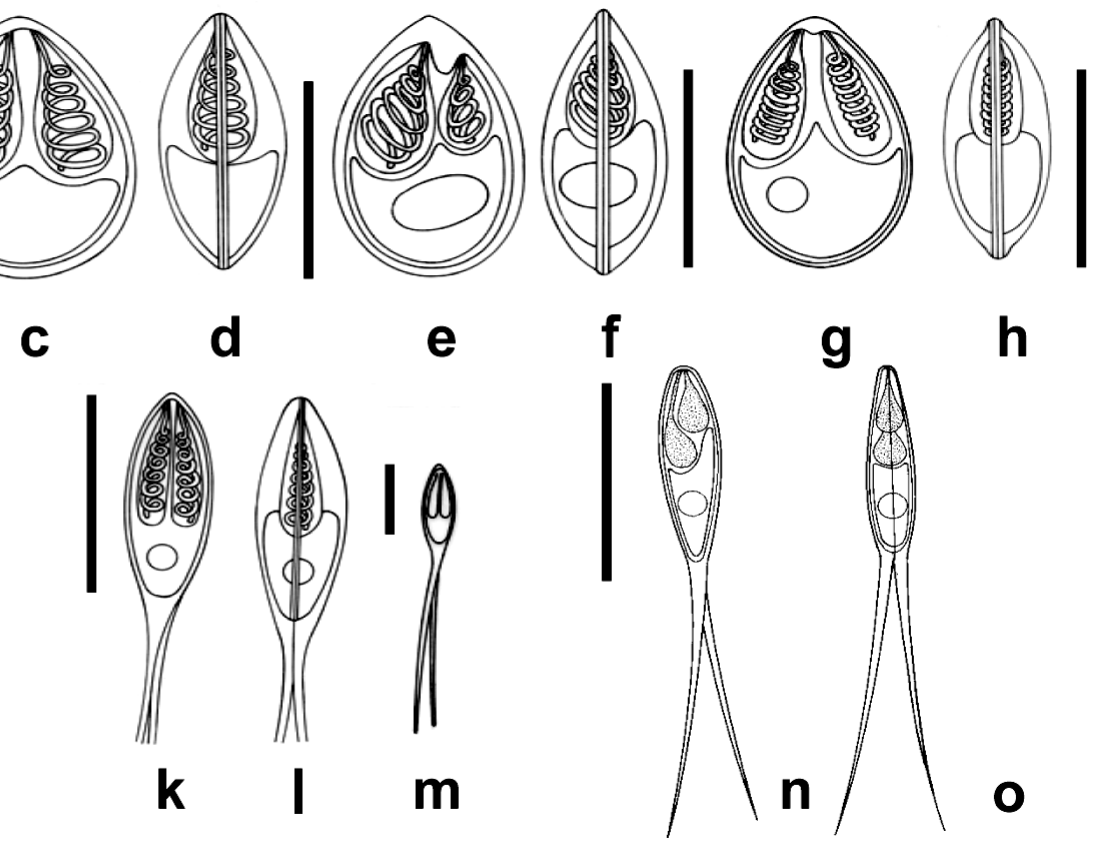

Fig. 1. Schematic drawings of spores of Myxobolus terengganuensis sp. nov., (a) frontal and (b) sutural view; M. tasikkenyirensis sp. nov., (c) frontal and (d) sutural view; M. csabai sp. nov., (e) frontal and (f) sutural view; M. osteochili sp. nov., (g) frontal and (h) sutural view; M. dykovae sp. nov., (i) frontal and (j) sutural view; Henneguya shaharini, (k) frontal view, (l) sutural view, (m) with complete caudal extensions; $H$. hemibagri, (n) frontal and (o) sutural view. Scale bars $=10 \mu \mathrm{m}$ 

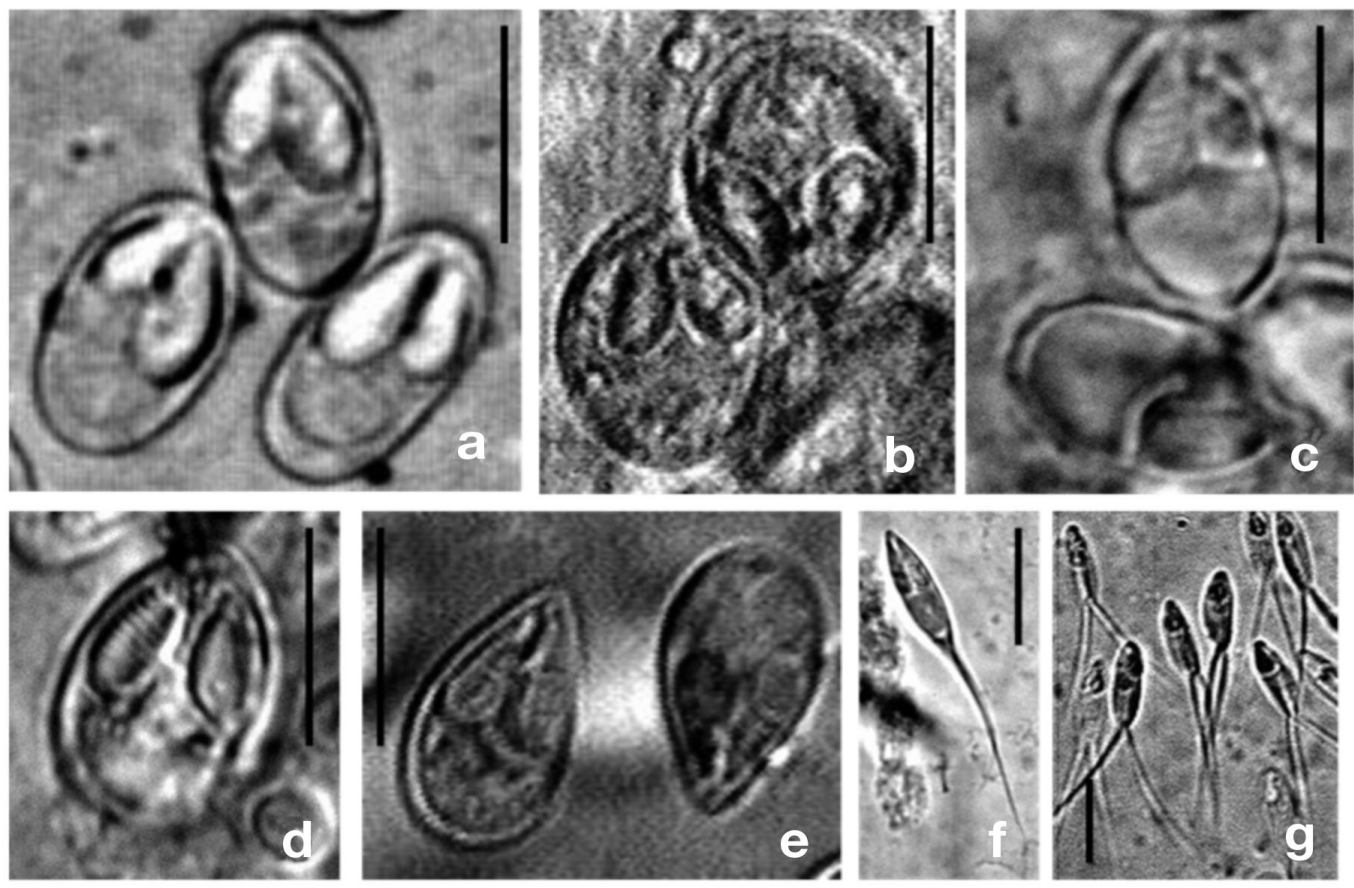

Fig. 2. Fresh spores of (a) Myxobolus terengganuensis sp. nov., (b) M. tasikkenyirensis sp. nov., (c) M. Csabai sp. nov., (d) M. osteochili sp. nov., (e) M. dykovae sp. nov., (f) Henneguya shaharini and (g) H. hemibagri. Scale bars $=10 \mu \mathrm{m}$

Prevalence of infection: $2 / 4$ of 16 to $18 \mathrm{~cm}$ sized fish.

Etymology: The species was named after the habitat of the host fish.

Spores: The spores (Figs. 1c \& 2b) were oval in frontal view, tapering at the anterior poles. In sutural view they were elongated ovals, tapering at both ends (Fig. 1d). Length of the spores was $12.8 \pm 0.72$ (range, 11.8 to 13.8) $\mu \mathrm{m}(\mathrm{n}=50)$, width $9.2 \pm 0.55$ (range, 8.3 to 9.9$) \mu \mathrm{m}$ $(\mathrm{n}=50)$, thickness 6 (range, 5.5 to 6.5$) \mu \mathrm{m}(\mathrm{n}=3)$. Polar capsules were elongated, equal in size, slightly converging anteriorly. Capsules were $6.4 \pm 0.42$ (range, 5.9 to 7.2$) \mu \mathrm{m}$ long $(\mathrm{n}=50)$ and $3 \pm 0.25$ (range, 2.7 to 3.4 ) $\mu \mathrm{m}$ wide $(\mathrm{n}=50)$. Five to six loosely wound filament coils were arranged perpendicularly to the capsule length in the polar capsule. Intercapsular appendix was absent. The width of the suture was about $5.5 \mu \mathrm{m}$. Sutural edge markings were not seen. A single binucleated sporoplasm with round iodinophilous vacuole was present. Mucous envelope was not found.

Histology: Cysts of larval trematodes and plasmodia were observed in close association in the musculature of the fish. Metacercariae seemed to be readily encysted in or close to plasmodia (Fig. 5).

Molecular data: Myxobolus tasikkenyirensis sp. nov. was on the same branch on the phylogenetic tree as M. csabai sp. nov. described in the next section (see Figs. $10 \& 11$ ). The similarity between their sequences was $96.5 \%$. The closest species available in GenBank were M. pellicides $(92.5 \%)$ and M. pendula $(91.9 \%)$.
Remarks: The spores lacking intercapsular appendix resemble many muscle-dwelling Myxobolus spp. but differ from the latter by their elongated, anteriorly converging polar capsules and by their DNA sequences. In its affinity to metacercarians, this species resembles $M$. uvuliferis infecting the pumpkinseed Lepomis gibbosus in North America, but differs from the latter species by its more elongated shape and by their genetically different hosts.

\section{Myxobolus csabai sp. nov.}

Type host: Silver shark minnow Osteochilus hasselti (Valenciennes, 1842) (Cyprinidae). Local name: ikan terbol.

Type locality: Lake Tasik Kenyir, Malaysia.

Site of tissue development: Round-shaped plasmodia with a diameter of 160 (range, 150 to 180) $\mu \mathrm{m}$ were found in the renal interstitium (Fig. 6). Aged spores were located in the melanomacrophage centers of the kidney.

Type material: Digitized photos of syntype spores and plasmodia were deposited in the parasitological collection of the Zoological Department, Hungarian Natural History Museum, Budapest, coll. no. HNHM70082. The 18S rDNA sequence of Myxobolus csabai sp. nov. was deposited in GenBank under accession no. EU643628.

Prevalence of infection: $5 / 10$ of 10 to $22 \mathrm{~cm}$ sized fish. 

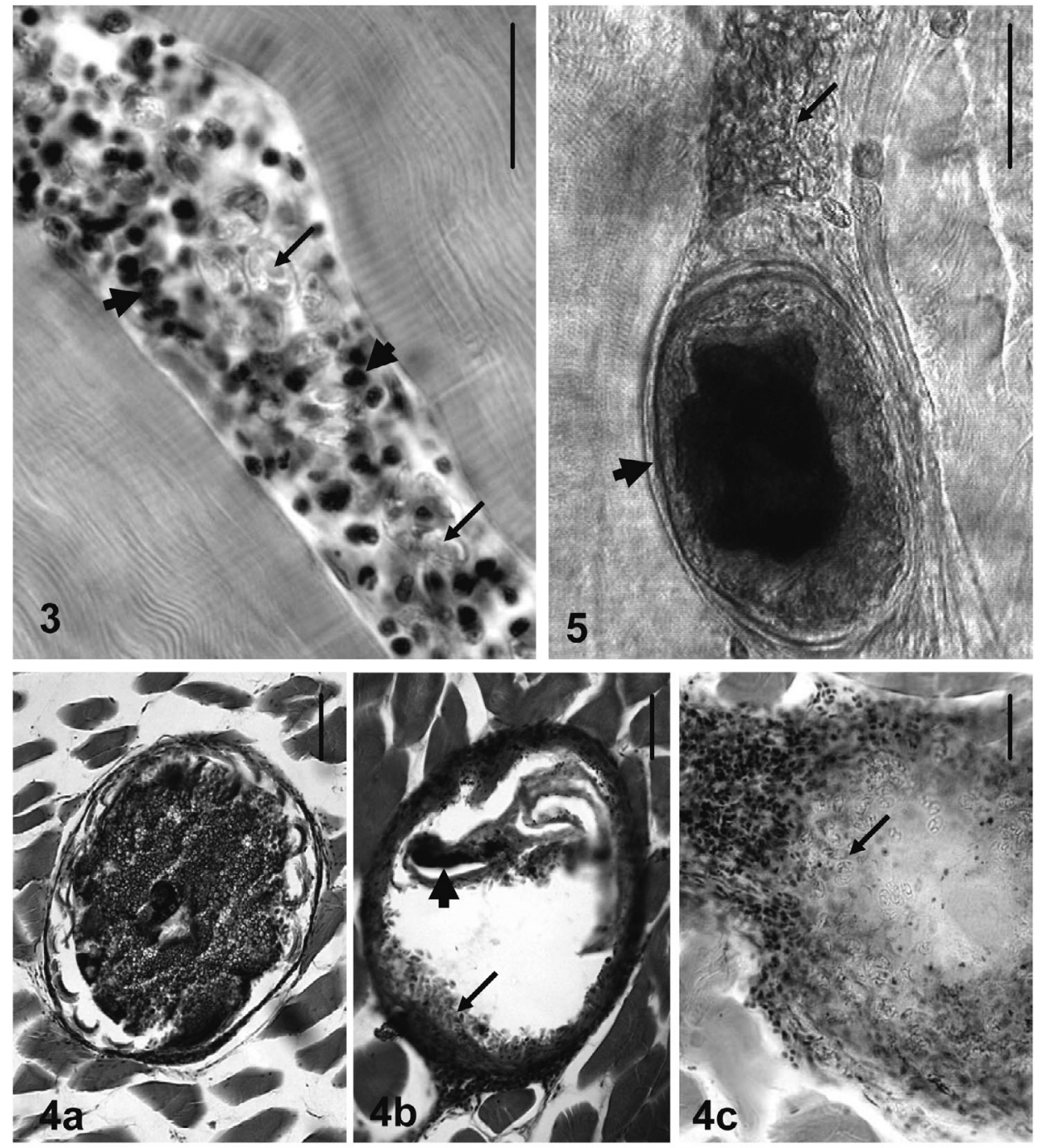

Figs. 3 to 5. Fig. 3. Spores (arrows) and melanomacrophage cells (arrowheads) located among undamaged muscle cells in the place of the disrupted Myxobolus terengganuensis sp. nov. plasmodium in Osteochilus hasselti. Histological section with hematoxylin and eosin (H\&E) staining. Scale bar $=25 \mu \mathrm{m}$. Fig. 4. (a) Trematode metacercaria in the musculature of $O$. hasselti. (b) Cyst of a decaying trematoda cercaria with the rest of the cercaria (arrowhead) and $M$. terengganuensis sp. nov. spores captured inside the capsule (arrow). (c) Parasitic nodule containing aged Myxobolus sp. spores, surrounded by melanomacrophage cells. Histological sections with H\&E staining. Scale bars $=50 \mu \mathrm{m}$. Fig. 5. A plasmodium of $M$. tasikkenyirensis sp. nov. filled with spores among muscle cells (arrow). A trematode metacercaria (arrowhead) seems to have developed in or close to the plasmodium. Fresh mount. Scale bar $=50 \mu \mathrm{m}$

Etymology: The species is named after György Csaba, the well-known Hungarian fish pathologist.

Spores: The spores (Figs. 1e \& 2c) were oval in frontal view, tapering at the anterior poles. In sutural view they were spindle-shaped (Fig. 1f). Length of the spores was $12.9 \pm 0.52$ (range, 12.1 to 14$) \mu \mathrm{m}(\mathrm{n}=50)$, width $8.6 \pm 0.49$ (range, 8.2 to 9.6$) \mu \mathrm{m}(\mathrm{n}=50)$, thickness $5 \pm 0.44$ (range, 4.7 to 5.6) $\mu \mathrm{m}(\mathrm{n}=15)$. Polar capsules were pyriform, different in size, slightly converging anteriorly. Larger capsule was $6.1 \pm 0.29$ (range, 6.4 to 6.8$) \mu \mathrm{m}$ long $(\mathrm{n}=50)$ and $3.8 \pm 0.14$ (range, 3.7 to 4.0) $\mu \mathrm{m}$ wide $(\mathrm{n}=50)$. Smaller capsule was $3.6 \pm 0.54$ (range, 3.3 to 4.8$) \mu \mathrm{m}$ long $(\mathrm{n}=50)$ and $2.3 \pm 0.36$ (range, 2.0 to 2.9$) \mu \mathrm{m}$ wide. Six densely wound filament coils were arranged obliquely to the capsule length in the polar capsule. A large intercapsular appendix located asymmetrically was present. The width of the suture was $6.6 \pm 0.19$ (range, 6.4 to 6.8) $\mu \mathrm{m}$. Sutural edge markings were not seen. A single binucleated sporoplasm with round iodinophilous vacuole was present. Mucous envelope was not found.

Molecular data. Myxobolus csabai sp. nov. and $M$. tasikkenyirensis sp. nov. were closely related, with 96.5\% similarity. Likewise, M. pellicides and M. pen- 

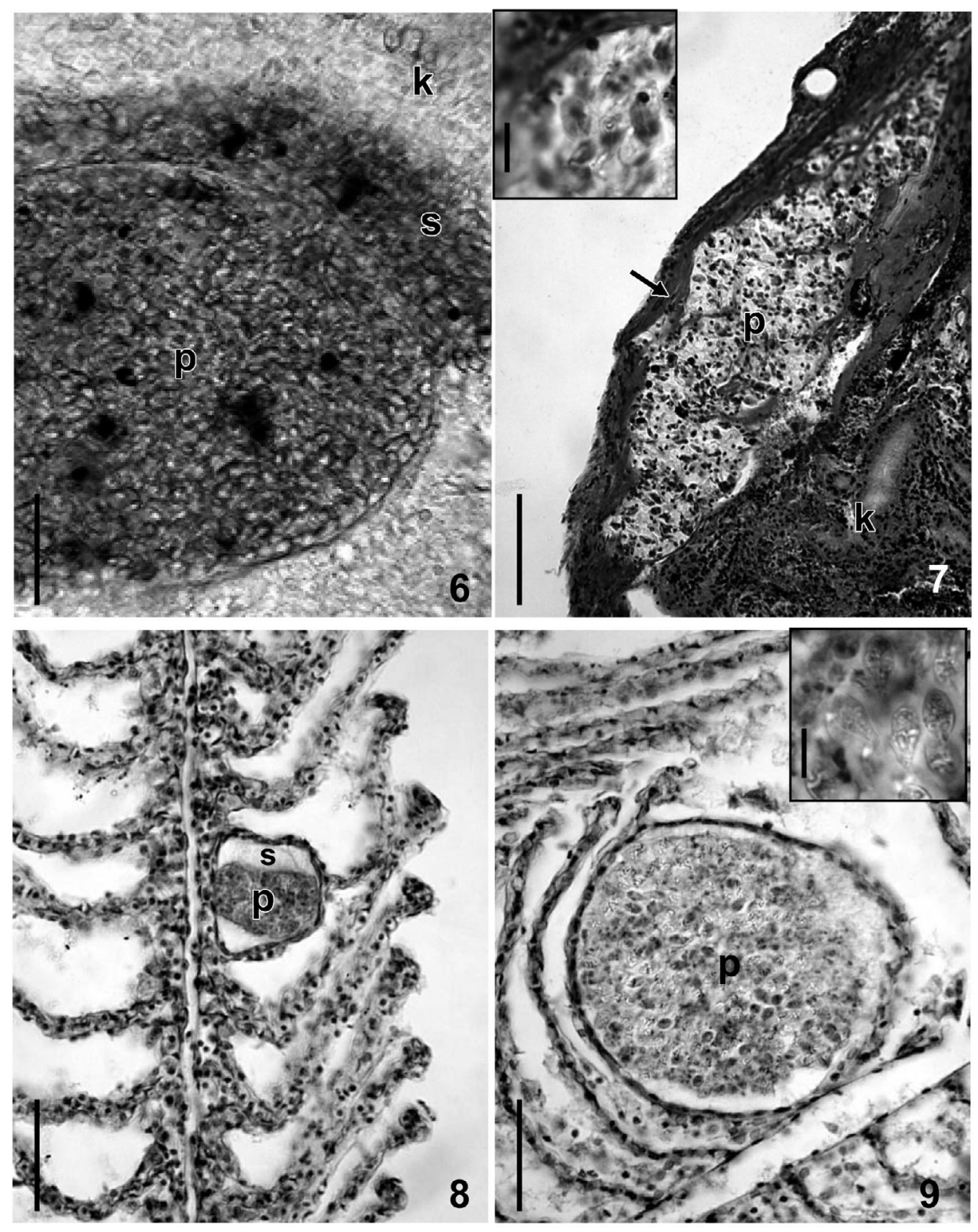

Figs. 6 to 9. Fig. 6. Myxobolus csabai sp. nov. plasmodium (p) in the interstitial part of the kidney (k). Some spores (s) were released from the compressed plasmodium. Fresh mounts. Scale bar $=25 \mu \mathrm{m}$. Fig. 7. Kidney of Osteochilus hasselti infected with groups of $M$. osteochili sp. nov. plasmodia (p). Plasmodia are located in the fibrous capsule (arrow) covering the parenchymal part of the kidney $(\mathrm{k})$. Inset: enlarged part of the plasmodium with spores. Histological section with H\&E staining. Scale bar $=100 \mu \mathrm{m}$ for the picture and $10 \mu \mathrm{m}$ for the inset. Fig. 8. A young M. dykovae sp. nov. plasmodium (p) in the gills of Barbonymus schwanenfeldii. The plasmodium is located inside a gill lamella. Around the plasmodium, serum fills the space inside the lamella. The tip of the lamella is undamaged. Histological section with H\&E staining. Scale bar $=50 \mu \mathrm{m}$. Fig. 9. A mature $M$. dykovae sp. nov. plasmodium (p) filled with spores (inset) in the gills of $B$. schwanenfeldii. Histological section with H\&E staining. Scale bar $=$ $50 \mu \mathrm{m}$ for the picture and $10 \mu \mathrm{m}$ for the inset

dula showed relatively high correspondence in their 18S rDNA with 91 to $92 \%$ homology.

Histology: No plasmodia were found in histological sections.

Remarks: By its large, asymmetrically located intercapsular appendix and by its DNA sequences this species differs from all known Myxobolus spp.

\section{Myxobolus osteochili sp. nov.}

Type host: Silver shark minnow Osteochilus hasselti (Valenciennes, 1842) (Cyprinidae). Local name: ikan terbol.

Type locality: Lake Tasik Kenyir, Malaysia.

Site of tissue development: Round plasmodia 
arranged in large groups in the fibrous capsule of the kidney.

Type material: Spores in glycerin-gelatin and histological sections were deposited in the parasitological collection of the Zoological Department, Hungarian Natural History Museum, Budapest, coll. no. HNHM70083. Sequence data for this species are being further studied by Szilvia Marton (Veterinary Medical Research Institute, Hungarian Academy of Sciences), and have not yet been submitted to GenBank.

Prevalence of infection: 6/13 of 10 to $22 \mathrm{~cm}$ sized fish.

Etymology: The species was named after the generic name of the fish host.

Spores: The spores (Figs. 1g \& 2d) were oval in frontal view, tapering at the anterior poles. In sutural view they were lemon shaped (Fig. 1h). Length of the spores was $13 \pm 0.63$ (range, 12 to 14 ) $\mu \mathrm{m}$ ( $\mathrm{n}=$ 50), width $8.7 \pm 0.45$ (range, 8 to 9$) \mu \mathrm{m}(\mathrm{n}=50)$, thickness $5 \pm 0.45$ (range, 4.5 to 5.5$) \mu \mathrm{m}(\mathrm{n}=15)$. Polar capsules were elongated, similar in size, $6.6 \pm$ 0.52 (range, 6 to 7$) \mu \mathrm{m}$ long $(\mathrm{n}=50)$ and $2.4 \pm 0.42$ (range, 2 to 3 ) $\mu \mathrm{m}$ wide $(\mathrm{n}=50)$. Eight to 9 densely wound filament coils were arranged perpendicularly to the capsule length in the polar capsule. In sutural view the thickness of the suture rim measured about $0.5 \mu \mathrm{m}$. The sutural rim protruded over the surface of the spore 1 to $1.2 \mu \mathrm{m}$ at the anterior pole, and 0.5 to $0.7 \mu \mathrm{m}$ at the posterior pole. No intercapsular appendix was found. Sutural edge markings were not seen. A single binucleated sporoplasm with a round iodinophilous vacuole was present. Mucous envelope was not found.

Molecular data: Comparison of Myxobolus osteochili in a pairwise alignment in BioEdit showed no close similarity with any of the Malaysian myxospores described here.

Histology: Plasmodia of this species were found in the fibrous capsule covering the kidney. In the infected portions of this capsule, large nodules were formed by groups of round-shaped plasmodia (Fig. 7). Free spores were also found in the melanomacrophage centers.

Remarks: Myxobolus osteochili corresponds to $M$. csabai in size and shape but differs from the latter species by its equal and elongated polar capsules and by the lack of an intercapsular appendix.

\section{Myxobolus dykovae sp. nov.}

Type host: Tinfoil barb Barbonymus schwanenfeldii (Bleeker, 1853) syn. Puntius schwanenfeldii Bleeker, 1853 (Cyprinidae). Local name: lampam sungai.

Type locality: Lake Tasik Kenyir, Malaysia.
Site of tissue development: Mature disporoblastic round-shaped plasmodia were found in the capillary network of the secondary lamellae in a vascular intralamellar position. Only old plasmodia filled with spores were seen.

Type material: Digitized photos of syntype spores and histological sections were deposited in the parasitological collection of the Zoological Department, Hungarian Natural History Museum, Budapest, coll. no. HNHM-70084. The 18S rDNA sequence of Myxobolus dykovae sp. nov. was deposited in GenBank under accession no. EU643627.

Prevalence of infection: $2 / 10$ of 5 to $25 \mathrm{~cm}$ sized fish.

Etymology: The species was named after Iva Dyková, the well-known Czech fish parasitologist.

Spores: The spores (Figs. 1i \& 2e) were oval both in frontal and sutural view, tapering at the anterior poles (Fig. 1j). Length of the spores was $12 \pm 0.50$ (range, 11 to 12.7$) \mu \mathrm{m}(\mathrm{n}=50)$, width $6.2 \pm 0.40$ (range, 5.6 to 6.7) $\mu \mathrm{m}(\mathrm{n}=50)$, thickness $5.8 \pm 0.16$ (range, 5.7 to 6.0) $\mu \mathrm{m}(\mathrm{n}=3)$. Polar capsules were equal in size and elongated, slightly converging anteriorly. Capsules were $6.0 \pm 0.07$ (range, 5.9 to 6.1 ) $\mu \mathrm{m}$ long $(\mathrm{n}=50)$ and $2.1 \pm 0.14$ (range, 2.0 to 2.3 ) $\mu \mathrm{m}$ wide $(\mathrm{n}=50$ ). Six to 7 filament coils were arranged perpendicularly to the capsule length in the polar capsule. No intercapsular appendix was present. Sutural edge markings were not seen. A single binucleated sporoplasm with round iodinophilous vacuole was present. Mucous envelope was not found.

Molecular data: The $18 \mathrm{~S}$ rDNA sequence of Myxobolus dykovae sp. nov. did not show a close relationship with any other Myxobolus spp. represented in GenBank because there is no Myxobolus species sequenced from this region. Only 91 to $92 \%$ identity with $M$. obesus, $M$. dujardini, $M$. intimus and $M$. hungaricus was found.

Histology: Round-shaped plasmodia of 50 to $70 \mu \mathrm{m}$ diameter were found intralamellary in the gills (Figs. 8 \& 9). Mature cysts deformed the neighboring lamellae by compressing them.

Remarks: Spores of this species most closely resemble the spores of Myxobolus carassii Klokacheva, 1914, a species common in goldfish in China, but differ from the latter by the less elongated shape of the spores and the more elongated shape of the polar capsules. Besides morphological differences there is a great genetic difference among the host fishes.

\section{Henneguya shaharini Shariff, 1982}

Host: Marble goby, Oxyeleotris marmoratus (Bleeker). Local name: ketutu.

Locality: Lake Tasik Kenyir, Malaysia. 
Site of tissue development: Gills.

Material: Digitized photos of syntype spores and histological sections were deposited in the parasitological collection of the Zoological Department, Hungarian Natural History Museum, Budapest, coll. no. HNHM70085. The 18S rDNA sequence of Henneguya shaharini was deposited in GenBank under accession no. EU643630.

Prevalence of infection: $1 / 2$ of 21 to $26 \mathrm{~cm}$ sized fish. Molecular data: The $1033 \mathrm{bp}$ long 18S rDNA fragment of Henneguya shaharini was very similar to those from other Henneguya spp. such as Henneguya lesteri, Henneguya pagri, Henneguya lateolabracis, Henneguya doori, and Henneguya gurlei, although even the highest similarity value did not exceed $75 \%$. The 18S rDNA nucleotide sequence of Hennegoides mekongiensis is available in GenBank and is 85.2\% similar to $H$. shakarini; however, it is only $435 \mathrm{bp}$ long. Henneguya mekongiensis could not be placed on the phylogenetic tree (Figs. 10 \& 11) because its extremely short sequence negatively affected the alignment and the construction of the tree.

Histology: Plasmodia with mature spores were found intralamellarly.

Remarks: Henneguya shaharini seems to be common on marble goby, as in addition to the present survey, similar infections were found also during a previous survey in 2004 from River Terengganu (K. Molnár \& Cs. Székely unpubl.). Round or ellipsoidal small plasmodia $100-120 \times 80-100 \mu \mathrm{m}$ in size developed intralamellarly in the gills. Spores found in both surveys corresponded to spores described by Shariff (1982).

\section{Henneguya hemibagri Tchang et Ma, 1993}

Host: Asian river (redtail) catfish Hemibagrus nemurus (Valenciennes). Local name: baung.

Location: Lake Tasik Kenyir, Malaysia. Site of infection: Plasmodia developed intralamellarly in the gills.

Prevalence of infection: $2 / 2$ of 23 to $27 \mathrm{~cm}$ sized fish.

Type material: Spores in glycerolgelatine were deposited in the parasite collection of the Hungarian National History Museum, coll. no. HNHM-70086.

Remarks: In morphology and size the spores found during the present survey correspond to the spores observed by Molnár et al. (2006b) from another locality (net-cage farms on Terengganu River).

\section{DISCUSSION}

Due to the great similarity of Myxobolus spp. spores, the identification of different species exclusively on morphological basis is rather difficult. Considering host specificity and location of vegetative developmental stages in organs and tissues is a great help in differentiating morphologically identical or similar spores, but a final answer to these questions can only be obtained by studying spores with molecular biological methods.

Little is known about the host specificity of myxosporeans, but earlier studies (Molnár 1994) suggest that some genera of myxosporeans have relatively

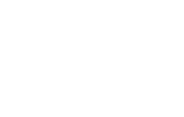

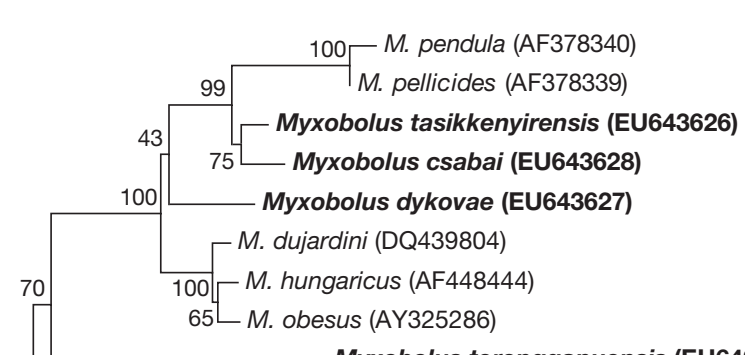

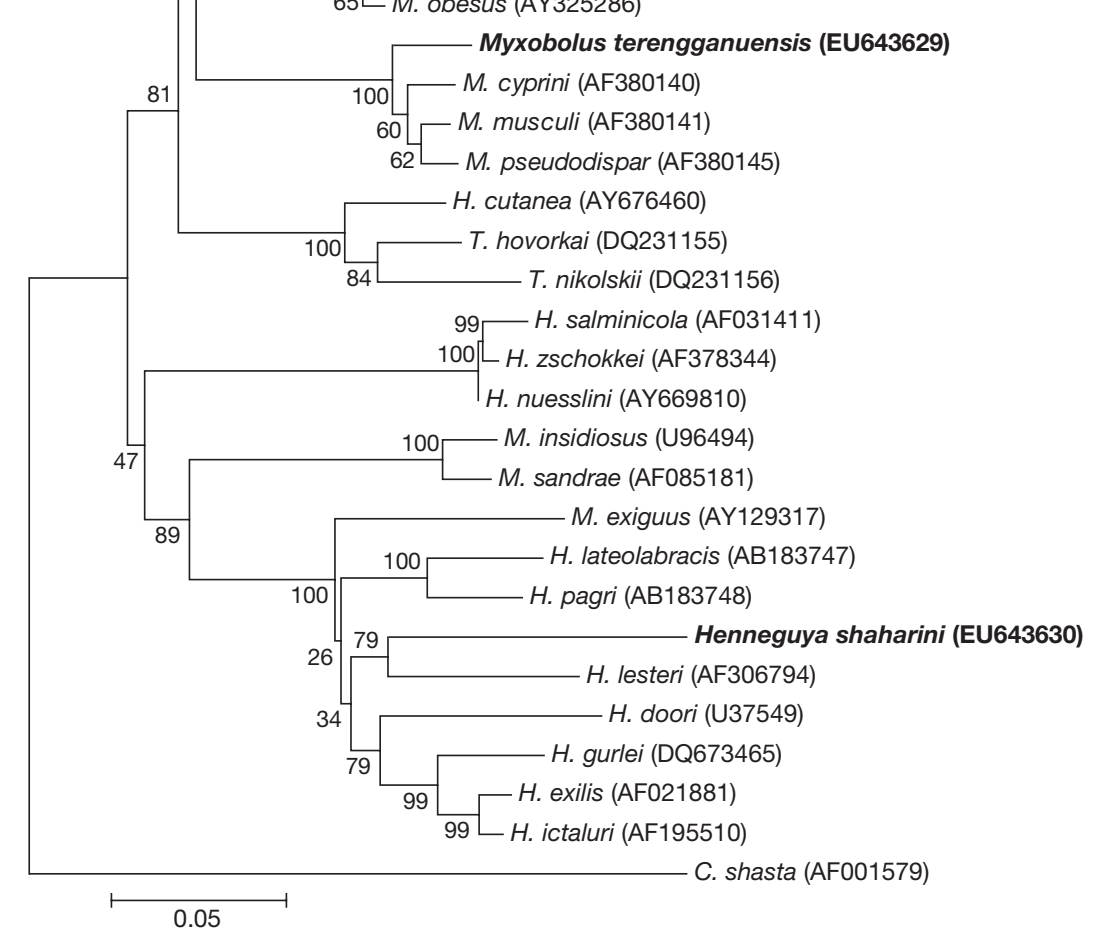

Fig. 10. Phylogenetic tree generated by neighbor-joining analyses of the $18 \mathrm{~S}$ rDNA sequences of myxosporeans, rooted at Ceratomyxa shasta. Numbers at nodes indicate bootstrap confidence values (1000 replications). GenBank accession numbers are given in parentheses. Myxosporeans examined in the present study are in bold. M.: Myxobolus; H.: Henneguya; T.: Thelohanellus 


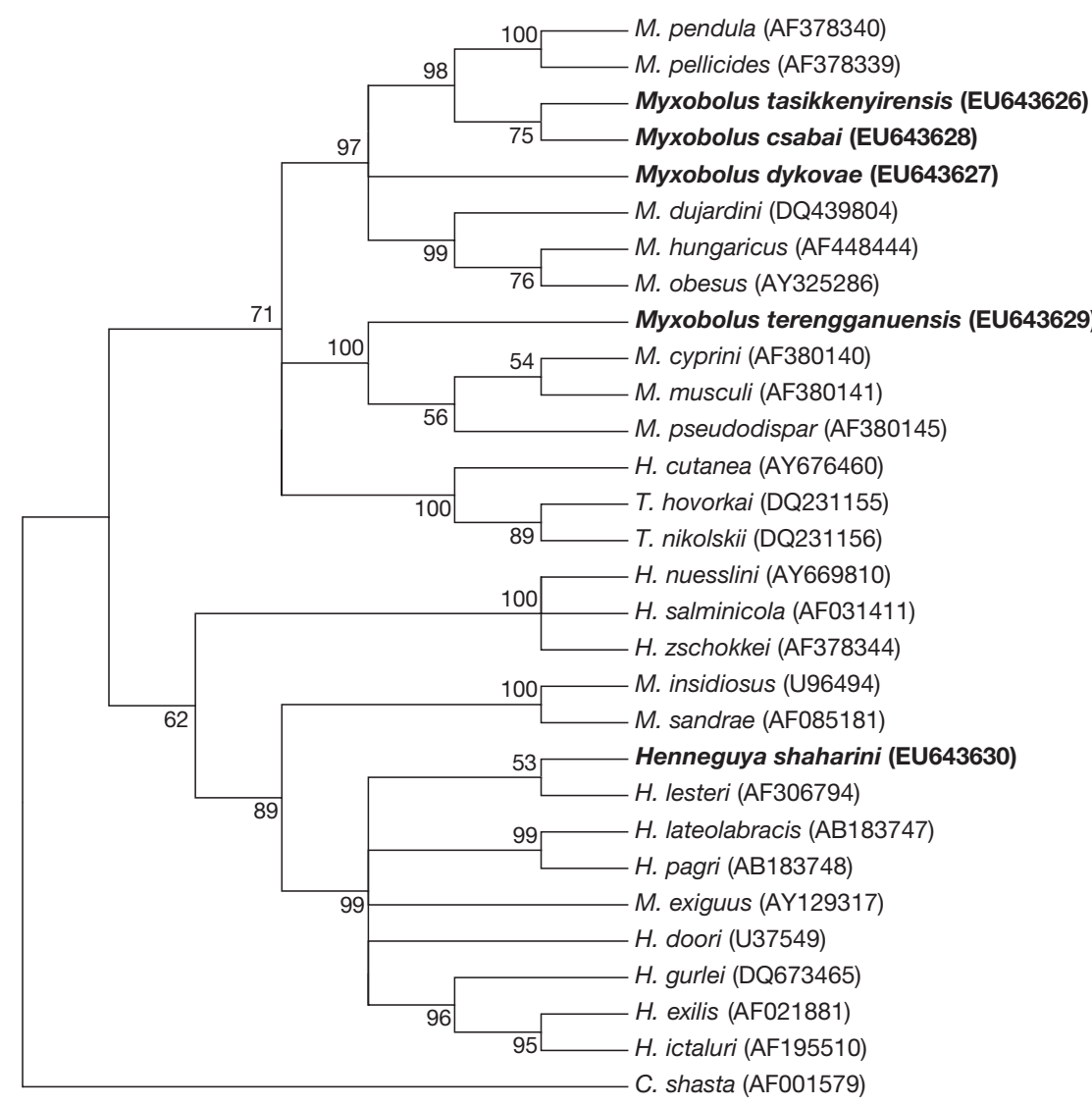

Fig. 11. Phylogenetic tree generated by maximum parsimony of the $18 \mathrm{~S}$ rDNA sequences of myxosporeans, rooted at Ceratomyxa shasta. Numbers at nodes indicate bootstrap confidence values (100 replications). GenBank accession numbers are given in parentheses. The branches under bootstrap value 50 were cut off. Myxosporeans examined in the present study are in bold M.: Myxobolus; H.: Henneguya; T.: Thelohanellus

strict host specificity and a given myxosporean species has only 1 or a few closely related fish hosts. The existence of relatively strong host specificity in the Мухоbolus genus has also been supported by molecular biological studies. Eszterbauer \& Székely (2004) reported that DNA sequences can clearly differentiate between morphologically similar species occurring in cyprinid fishes. In a similar way, clear molecular differences were found among Myxobolus spp. collected during the present study. Accepting this general rule, most of the endemic Malaysian species might have specific Myxobolus spp. which should be described as new ones. Myxosporean species common in other biotopes of the world can occur in southeast Asia, mostly in introduced fishes such as common carp, silver carp, goldfish or Tilapia and Batrachus spp.

The organ and tissue specificity of these myxosporeans also seems to be common (Molnár et al. 2002). Two of the Myxobolus spp. studied here ( $M$. terengganuensis sp. nov. and M. tasikkenyirensis sp. nov.) had defi- nite tissue tropism towards the muscle cells, while in the case of $M$. csabai sp. nov. and M. osteochili sp. nov., the specific location of plasmodium stages was the kidney. M. dykovae sp. nov. formed cysts in the gills of its host, and its plasmodia developed in the capillary network of the secondary lamellae in a vascular intralamellar position (see Molnár 2002). Both species found in the muscles had an intracellular route of development. Although M. terengganuensis and M. tasikkenyirensis are typical intracellular parasites of the muscle cells, the common occurrence of their spores inside the cysts of larval trematodes needs further explanation. The affinity of myxosporean spores to larval trematodes is already known; Cone \& Anderson (1977) described M. uvuliferis from the cysts of Uvulifer ambloplitis metacercariae infecting the pumpkinseed Lepomis gibbosus in Canada. Those authors surmised that the cercariae invaded portions of the muscle which already contained myxosporeans and that the capsule might have originally been a myxosporean cyst. Our findings support this theory and our pictures (Figs. $3 \& 4$ ) show that the metacercarian stages are actually formed inside a M. tasikkenyirensis cyst. Cone \& Anderson (1977) found both spores and young plasmodia inside the metacercarian cyst. In our case, in $M$. terengganuensis and $M$. tasikkenyirensis infections, only disseminated spores inside trematode cysts and cysts with mature spores associated to metacercarians were found. We suggest that metacercariae invading the muscles of fish prefer tissue portions where plasmodia disintegrate their host cells and spores are released into the intercellular space. Obviously most of the released spores leave this location due to compression of the musculature but a certain number of spores remain on the spot and become surrounded by granulation tissue, as was found in the case of $M$. terengganuensis sp. nov.

Some of the fish species of Tasik Kenyir studied by us are commercially important fishes regularly seined or to be cultured in fish farms or cage systems in the future, so their myxosporean infection could become an economic problem. Among the fishes examined during the present survey, we found moderately infected and severely infected specimens. During the short term of the examinations, no disease symptoms were recorded and at present we cannot give data on 
the pathogenicity of the myxozoan infections of Tasik Kenyir fishes. The large number of myxozoan species, the intensive infection of some fish specimens and the local changes around the parasites, however, suggest the possibility that in intensive culture systems, more severe symptoms and losses might also appear.

Of the species studied in the present survey, neither Myxobolus nor Henneguya spp. showed strict relationships in their DNA sequence to species in GenBank, because the sequences of myxobolid species deposited in Genbank are mostly from Europe, North America or China. Nevertheless some interesting observations can be made. $M$. terengganuensis was on the phylogenetic tree next to the $M$. cyprini group, which it resembles morphologically. M. tasikkenyirensis is also a muscleinfecting parasite, but its phylogenetic position is far away from $M$. terengganuensis. Its closest relative is M. csabai, which develops in the host's renal interstitium. There is only a low similarity between $M$. dykovae and the European M. dujardini, M. obesus and $M$. hungaricus, but these species infect gills, as does $M$. dyakovae. Henneguya sharini does not have any close relative among the sequenced species.

Acknowledgements. The authors thank the staff of AQUATROP (UMT) and K. Mohamed (UMT) for their help in the laboratory work and fish collections. The work was financially supported by the University Malaysia Terengganu and partially by the Hungarian Research Grant OTKA K 71837.

\section{LITERATURE CITED}

Arthur JR, Te QB (2006) Checklist of the parasites of fishes of Viet Nam. FAO Fish Tech Pap 369/2. FAO, Rome

Basu S, Haldar DP (2003) Three new species of Myxobolus Butschli, 1882 from different food fishes of West Bengal, India. Acta Protozool 42:245-251

Basu S, Haldar DP (2004) Description of three new myxosporean species (Myxozoa: Myxosporea: Bivalvulida) of the genera Myxobilatus Davis, 1944 and Myxobolus Butschli, 1882. Acta Protozool 43:337-343

Chakravarty MM (1939) Studies on Myxosporidia from the fishes of Bengal, with a note on myxosporidian infection in aquaria fishes. Arch Protistenkd 92:169-178

Cone DK, Anderson RC (1977) Myxosporidan parasites of pumpkinseed (Lepomis gibbosus L.) from Ontario. J Parasitol 63:657-666

Eiras JC (2002) Synopsis of the species of the genus Henneguya Thélohan, 1892 (Myxozoa: Myxosporea: Myxobolidae). Syst Parasitol 52:43-54

Eiras JC, Molnár K, Lu YS (2005) Synopsis of the species of Myxobolus Bütschli, 1882 (Myxozoa: Myxosporea: Myxobolidae). Syst Parasitol 61:1-46

Eszterbauer E (2004) Genetic relationship among gill-infecting Myxobolus species (Myxosporea) of cyprinids: molecular evidence of importance of tissue-specificity. Dis Aquat Org 58:35-40

Eszterbauer E, Székely C (2004) Molecular phylogeny of the kidney-parasitic Sphaerospora renicola from common carp (Cyprinus carpio) and Sphaerospora sp. from gold- fish (Carassius auratus auratus). Acta Vet Hung 52: 469-478

Hall TA (1999) BioEdit: a user-friendly biological sequence alignment editor and analysis program for Windows 95/98/NT. Nucleic Acids Res 41:95-98

Hillis DM, Dixon T (1991) Ribosomal DNA: molecular evolution and phylogenetic inference. Q Rev Biol 66:411-453

Ky H (1971) Some freshwater myxosporean species from North Vietnam. Acta Protozool 8:283-298 (in Russian with English Abstract)

> Lalitha-Kumari PS (1965) On a new species of Henneguya (Protozoa: Myxosporidia) from Indian freshwater fish, Ophiocephalus gachua. Riv Parassitol 26:79-84

Lalitha-Kumari PS (1969) Studies on parasitic protozoa (Myxosporidia) of freshwater fishes of Andhra Pradesh, India. Riv Parassitol 30:154-225

Levsen A, Alvik T, Grotmol S (2004) Neurological symptoms in tricolor sharkminnow Balantiocheilos melanopterus associated with Myxobolus balantiocheili n. sp. infecting the central nervous system. Dis Aquat Org 59:135-140

Lom J, Arthur JR (1989) A guideline for preparation of species description in Myxosporea. J Fish Dis 12:151-156

Lom J, Dyková I (1997) Light and electron microscope observations on Sphaerospora ojiroveci n. sp. (Myxozoa) from the kidney of Pangasius sutchi (Teleostei). Eur J Protistol 33:444-451

Lom J, Dyková I (2006) Myxozoan genera: definition and notes on taxonomy, life-cycle terminology and pathogenic species. Folia Parasitol 53:1-36

> Lom J, Tonguthai K, Dyková I (1991) Hennegoides longitudinalis n. gen. n. sp., a myxosporean parasite of Osphronemus gourami from Thailand. Dis Aquat Org 11:143-145

Molnár K (1994) Comments on the host, organ and tissue specificity of fish myxosporeans and on the types of their intrapiscine development. Parasit Hung 27:5-20

> Molnár K (2002) Site preference of fish myxosporeans in the gill. Dis Aquat Org 48:197-207

> Molnár K, Eszterbauer E, Székely C, Dán Á, Harrach B (2002) Morphological and molecular biological studies on intramuscular Myxobolus spp. of cyprinid fish. J Fish Dis 25:643-652

Molnár K, Székely Cs, Mohamed K, Shaharom-Harrison F (2006a) Myxozoan pathogens in cultured Malaysian fishes. I. Myxozoan infections of the sutchi catfish Pangasius hypothalmus in freshwater cage cultures. Dis Aquat Org 68:209-218

- Molnár K, Székely Cs, Mohamed K, Shaharom-Harrison F (2006b) Myxozoan pathogens in cultured Malaysian fishes. II. Myxozoan infections of redtail catfish Hemibagrus nemurus in freshwater cage cultures. Dis Aquat Org 68:219-226

Sarkar NK (1985) Myxosporidian Henneguya mystusia sp. n. (Myxozoa: Myxosporea) from the gills of a freshwater teleost fish Mystus sp. Acta Protozool 24:55-58

Sarkar NK (1986) On two new species of Myxobolus Butschli, 1882 (Myxozoa, Myxosporea) from the fresh-water fishes of West-Bengal, India. Acta Protozool 25:235-239

Sarkar NK (1995) Observations on two new myxosporidia (Myxozoa, Myxosporea) from fishes of Bhery-Fishery of West-Bengal, India. Acta Protozool 34:67-70

Sarkar NK, Mazumder SK, Pramanik A (1985) Observation of four new species of myxosporidia (Myxozoa) from channid (Ophiocephalid) fishes of West Bengal, India. Arch Protistenkd 130:289-296

Seenappa D, Manohar L (1981) Five new species of Myxobolus (Myxosporea, Protozoa), parasitic in Cirrhina mrigala (Hamilton) and Labeo rohita (Hamilton), with a note on a 
new host record for Myxosporea curmucae Seenappa and Manohar. J Protozool 28:358-360

Shariff M (1982) Henneguya shaharini sp. nov. (Protozoa: Myxozoa), a parasite of marble goby, Oxieleotris marmoratus (Bleeker). J Fish Dis 5:37-45

Supamattaya K, Fischer-Scherl T, Hoffmann RW, Boonyaratpalin S (1991) Sphaerospora epinepheli n. sp. (Myxosporea: Sphaerosporidae) observed in grouper (Epinephelus malabaricus). J Protozool 38:448-454

Swofford DL (2000) PAUP*. Phylogenetic analysis using parsimony ( ${ }^{*}$ and other methods). Version 4. Sinauer Associates, Sunderland, MA

Tamura K, Dudley J, Nei M, Kumar S (2007) MEGA4: molecular evolutionary genetics analysis (MEGA) software ver-

Editorial responsibility: Dieter Steinhagen,

Hannover, Germany sion 4.0. Mol Biol Evol 24:1596-1599

Thompson JD, Higgins DG, Gibson TJ (1994) CLUSTAL W: improving the sensitivity of progressive multiple sequence alignment through sequence weighting, position-specific gap penalties and weight matrix choice. Nucleic Acids Res 22:4673-4680

Tripathi YR (1952) Studies on parasites of Indian fishes. Protozoa: Myxosporidia together with a check-list of parasitic protozoa described from Indian fishes. Rec Indian Mus 50:63-88

Zulkafli AR, Ashhar AO (2000) Fish fauna in Tasik Kenyir. Freshwater Fisheries Research Centre, Batu Berendam, Melaka. Available at: www.fri.gov.my/pppat/kenyirweb/ index.htm

Submitted: June 11, 2008; Accepted: September 23, 2008 Proofs received from author(s): December 5, 2008 